\title{
TRÊS MARCAS (ESTIGMAS) DE OCKHAM NO PENSAMENTO DE HOBBES (O subsídio ockhamiano ao pensamento Hobbesiano)
}

\author{
Alfredo Culleton*
}

\begin{abstract}
SÍNTESE - Sempre mais está sendo constatado que entre Thomas Hobbes e Guilherme de Ockham existe uma proximidade que não é apenas circunstancial ou só de palavras. Hobbes depende dos medievais muito mais do que admite. No presente trabalho examinam-se três casos de conceitos afins entre os dois autores.

PALAVRAS-CHAVE - Filosofia política medieval. Filosofia política moderna. Ockham. Hobbes. Afinidade entre os dois autores.

ABSTRACT - It has become noticeable nowadays that between Thomas Hobbes and William Ockham there is a proximity which is not only circumstancial or merely verbal. Hobbes relies much more on medieval writers than is willing to concede. In the present article, I proceed to examine there cases of concepts akin to both authors.

KEY WORDS - Medieval political philosophy. Modem political philosophy. Hobbes. Ockham.
\end{abstract}

"One still finds the echoes of Ockham's semantics at the beginning of Hobbes's Leviathan."1

Apesar da distância cronológica de mais de dois séculos que separam os dizeres de Ockham dos de Hobbes, encontramos entre eles não só o fato de serem naturais da mesma ilha e de freqüentarem o mesmo centro de estudos, e a mesma biblioteca desse santuário que é Oxford, mas também o fato de o primeiro contratualista moderno haver-se hospedado durante anos, por motivo do seu exilio em Paris, no convento dos franciscanos, que contava com a maioria dos escritos do venerabilis Inceptor.

No que se refere ao estritamente filosófico, quero destacar três pares de gens no pensamento de Hobbes que, sem muito esforço, posso evidenciar como pertencentes ao DNA de William Ockham. O primeiro é acerca da linguagem no processo de conhecimento; o segundo é o papel fundamental do nominalismo na instituição do soberano e o terceiro é o anticlericalismo quando se fala no poder eclesiástico.

* Universidade do Vale do Rio dos Sinos - Unisinos, São Leopoldo, RS.

Normore, Calvin. "Some Aspects of Ockham's Logic, in The Cambridge Companion to Ockham", Ed. By Paul V. Spade, Cambridge University Press, 1999.

\begin{tabular}{|l|l|l|l|l|l}
\hline VERITAS & Porto Alegre & v. 45 & n. 3 & Setembro 2000 & p. $411-416$ \\
\hline
\end{tabular}




\title{
1 Linguagem e racionalidade
}

O que existe na natureza de cada indivíduo, de acordo com Hobbes, é a capacidade de inventar a linguagem e com ela o raciocínio.

"Os gregos têm uma só palavra, logos, para linguagem e razão, não que eles pensassem que não havia linguagem sem razão, mas sim que não havia raciocinio sem linguagem." ${ }^{2}$

A linguagem torna-se um elemento fundamental para o exercício ou a construção da racionalidade. Hobbes afirma, explicitamente, que o raciocínio e a ciência conhecimento racional - dependem da capacidade de invenção da linguagem. Só uma correta ordenação de nomes deve levar a conclusões necessárias e universais.

"Por aqui se vê que a razão não nasce conosco como a sensação e a memória, nem é adquirida apenas pela experiência, como a prudência, mas obtida com esforço, primeiro através de uma adequada imposição de nomes, e em segundo lugar, através de um método bom e ordenado de passar dos elementos, que são nomes, a asserções feitas por conexão de um deles com o outro, e daí para os silogismos, que são as conexões de uma asserção com outra, até chegar a um conhecimento de todas as conseqüências de nomes referentes ao assunto em questão, e é a isto que os homens chamam ciência." ${ }^{3}$

Só pela linguagem é possivel construir consequiências necessárias e de validade universal: propriedades essenciais do cálculo racional. Não haveria raciocínio sem nomes universais, uma vez que de duas proposições particulares nada se conclui.

"Alguns nomes são próprios, e singulares a uma só coisa, como Pedro, João, este homem, esta árvore; e alguns são comuns a muitas coisas, como homem, cavalo, árvore, cada um dos quais, apesar de ser um só nome, é contudo o nome de várias coisas particulares, em relação às quais em conjunto se denomina universal, nada havendo no mundo universal além de nomes, pois as coisas nomeadas são, cada uma delas, individuais e singulares." ${ }^{4}$

A universalidade, para Hobbes, é uma propriedade exclusiva dos nomes e "enganam-se a si mesmos ao tomarem o universal, ou a denominação geral, pela coisa que essa denominação significa", diz ele, concluindo o parágrafo de maneira contundente: "portanto, é claro que não há nada universal exceto os nomes". ${ }^{5}$ Vemos aqui o perfil nominalista e profundamente cético da doutrina hobbesiana, como comenta Oakeshott: ${ }^{6}$

"a verdade para Hobbes é verdade de universais, mas eles são nomes, os nomes de imagens deixadas pela sensação, e uma proposição verdadeira não é uma asserção acerca do mundo real. Nós podemos, desta maneira, superar os limites da sensaçãoexperiência para alcançar o conhecimento racional."

\author{
Lev. 4, p. 26. \\ Lev. 5 p. 30 \\ Lev IV p. 21. Cf. Nat. Humana 5,5 e De Corpore 2, 11 \\ Nat. Humana 5,6 p. 23 \\ OAKESHOTT, Michael, 1975 p. 23
}


A realidade não é universal, nem mesmo a idéia a ela referida. O que há, segundo Hobbes, são nomes universais, ou seja, um nome universal que pode ser atribuído a muitas coisas, devido a sua semelhança com alguma qualidade ou acidente. Os nomes não são senão sinais ou marcas de lembranças que recordam, de modo universal, as qualidades das coisas. Onde não houver linguagem, não há verdade nem falsidade, porque a linguagem é a referência da realidade, construída pela ciência.

Não há coisas reais nem idéias universais. Os nomes, pelo contrário, por sua virtude significante, podem fazer pensar não só a idéia de uma coisa determinada, mas também a idéia de uma coisa qualquer, não determinada, dentro de um conjunto de coisas semelhantes. Um nome universal, para Hobbes, pode ser atribuído a muitas coisas, devido a sua semelhança em alguma qualidade, ou outro acidente; e, enquanto o nome próprio traz ao espírito uma coisa apenas, os universais recordam qualquer dessas muitas coisas, porque os nomes não são senão sinais ou marcas de lembrança.

Como não há raciocínio sem nomes, também não há raciocínio sem a formação de proposições com os nomes, pois o raciocínio é uma consequiência que transporta a verdade dos princípios às conclusões. De acordo com Hobbes, a verdade é uma propriedade exclusiva da linguagem proposicional. A verdade consiste na adequada ordenação de nomes em nossas afirmações, formando significados.

"Ouando dois nomes estão ligados numa consequiência, ou afirmação, como por exemplo 'O homem é um ser vivo', ou esta outra, 'se ele for um homem, é um ser vivo', se o último nome ser vivo significa tudo o que o primeiro nome significa, então a afirmação, ou conseqüência, é verdadeira; de outro modo é falsa. Pois o verdadeiro e o falso são atributos da linguagem, e não das coisas. $E$ onde não houver linguagem, não haverá verdade ou falsidade."

Isto parece copiado de Ockham quando distingue os dois tipos de saber, isto é, o real e o racional.

\section{De como se constitui o soberano, uma teoria nominalista do estado}

O problema que enfrentamos ao ler a teoria do estado de Hobbes é precisamente saber como é que acontece a passagem de uma multitudo de indivíduos em estado de natureza para um corpo político. Para instituir o soberano, aquele que dará unidade à multiplicidade de interesses individuais, é necessário transferir alguma coisa destes em favor dum outro para se tornar um. "A única maneira de constituir um tal poder comum [...] é conferir todo o poder e força para uma única pessoa, ou assembléia." A fato é que se torna impossível transferir poder ou força a outrem. ${ }^{9}$ Os homens não podem literalmente transferir seu poder ou força, assim como também não podem transferir a sua vontade ou um direito que eles mesmos não têm antes de instituído o soberano, a não ser que seja por analogia.

Cf. Lev IV p. 23

Lev. IV p. 23. Cf. Nat Humana V, 10.

Ver Elements 19, 10 "it's impossible for any man really to transfer his own strenght to another". 
A alternativa possivel, sugerida por Watkins ${ }^{10}$ é que seja o nome. A autoridade do soberano reside na capacidade de atuar em nome de "representá-lo [...] ou atuar em seu nome". ${ }^{11}$ Isto é, autorizar alguém para atuar em nome de cada um para determinar o justo e o injusto, o certo e o errado.

Existe um vinculo entre o desenvolvimento da linguagem e, necessariamente, o da ciência, com a existência de um "grande Estado". Estado que, ao mesmo tempo, deve ser instituído por força da razão, exercendo um papel fundamental na construção da linguagem.

"A experiência não conclui nada universalmente [...] não podemos afirmar por experiência que uma coisa seja justa ou injusta, verdadeira ou falsa, nem qualquer tipo de proposição universal, a não ser através da lembrança do uso dos nomes arbitrariamente impostos pelos homens."

Se as proposições universais estão no uso dos nomes, no correto uso dos nomes, tanto no significado, que será arbitrário, quanto no método, que pretenderá universalidade, na linguagem residirá a Razão. ${ }^{13}$

Podemos dizer que o soberano hobbesiano é instituído para resolver um problema epistemológico na medida em que os indivíduos carecem de critérios objetivos para estabelecer o significado dos termos necessários para estabelecer relações com os outros; termos, tais como, bom, mau, certo, errado, justo, injusto, devido ou proibido. E como o sentido esses termos não são mais do que nomes, 0 principal e fundamental papel do soberano será o de dar um significado unívoco aos termos que propiciam conflitos e a guerra de todos contra todos. Podemos dizer com Michael Oakeshott: "Hobbes philosophy lies in his conception of the nature of the philosophical knowledge, and not in any doctrine about the world."

O soberano não terá a função de zelar pelo cumprimento das regras do cálculo ou da corrèta formulação dos silogismos ou de cuidar que seus súditos não incorram em erro no uso da linguagem. A função do soberano será a de preservar a vida dos seus instituintes fundamentalmente através do exercício do seu poder epistêmico, de determinar o sentido das palavras na linguagem pública, e, assim, induzir os súditos a concordar no significado de "bem" e "mal". A não determinação do sentido desses termos é a principal fonte de conflitos na vida em sociedade. De tal maneira que o nominalismo atribuído a Hobbes, que à primeira vista parece contracenar com o racionalismo, só serve como confirmação e fundamentação deste. A palavra, tal como Hobbes a trabalha, é o ponto de apoio e o veículo de conhecimento racional, a que leva à nossa consciência o reconhecimento de sua validade universal.

\footnotetext{
WATKINS, John. Hobbes System of Ideas, Gower, Great Britain, 1989.

Lev. 18.

El. $4,10-11$.

Lev. 5.
} 


\section{Da limitação do poder eclesiąl}

Numa carta escrita ao Earl of Devonshire em 1642, como atesta Ferdinand Tönnies no seu clássico sobre Hobbes, o autor do Leviatã diz que "a disputa entre o poder espiritual e o civil, tem sido ultimamente, mais do que qualquer outra coisa no mundo, a causa da guerra civil".

Encontramos em Hobbes o mesmo tema, urgência e discurso, ainda que com algumas variações, enfrentados por Ockham dois séculos antes. O tema do poder eclesiástico é o título e o protagonista do mais extenso dos capítulos do Leviatã, o XLII, apesar de não ter sido, como não o foi para Ockham, o objeto principal dos seus tratados.

Um dos temas decorrentes nas disputas ockhamianas, acerca dos poderes civil e eclesiástico, é o da "liberdade cristã", coincidentemente, conceito-chave no argumento do último e conclusivo capítulo do Leviatã. Nele, o autor faz uma breve história genealógica da Igreja. No começo, diz o texto, os cristãos obedeciam aos Apóstolos por causa das suas virtudes, e "a modo de reverência e não de obrigação". Depois, com o advento da cristandade, o clero começou a se reunir em assembléias para acordar as doutrinas que devia ensinar. Pretendia "que as pessoas pensassem que estavam obrigadas a seguir suas doutrinas e, no caso de serem rejeitadas, eram expulsos da comunidade, não por serem infiéis, mas por serem desobedientes". Este foi o começo da violência à liberdade dos leigos. Era, diz Hobbes, "o primeiro nó em sua liberdade". Mais tarde, o número dos presbíteros aumentou, aqueles das cidades importantes e províncias assumiram uma autoridade sobre os presbíteros paroquiais e apropriaram-se do nome de bispos. Assim, diz Hobbes, "foi um segundo nó na liberdade cristã". Finalmente, o bispo da mais importante das cidades - Roma - adquiriu poder sobre os outros bispos, e o terceiro nó estava dado, assim fica resumida "toda a síntese e construção do poder pontificial".

O argumento hobbesiano subverte a leitura clássica de Cristo a Pedro e de Pedro aos seus sucessores, mas atribui como fundamento último do poder eclesial à ambição pessoal de alguns presbíteros que agem de acordo com critérios de poder político. Isto se constituía num engodo para os cristãos dado que no lugar de colaborar com as suas vidas acabava envolvendo-os em disputas, guerras e morte. $\mathrm{O}$ desafio proposto por Hobbes é o de percorrer o caminho contrário desamarrando os nós e resgatando a "liberdade cristã" para voltar "à autonomia dos primeiros cristãos".

Sem deixar de reconhecer a superioridade dos fins espirituais sobre os temporais, isto não supõe, para Hobbes, a superioridade do poder espiritual sobre 0 temporal, isto é, mesmo que o Papa tivesse poder espiritual ainda assim os príncipes não lhe seriam submetidos. ${ }^{14}$ A idéia central no Leviatã é a de que o clérigo não tem poder de nenhum tipo. Parte do princípio de que o Reino de Deus, no dizer do próprio Cristo, não é deste mundo, de tal maneira que os seus ministros

${ }^{14}$ Lev. 42 
carecem de qualquer autoridade na terra. A função deles não seria a de comando mas a de persuação. $O$ termo governo espiritual seria um simples engano, já que "não há [...] nenhum outro governo nesta vida, nem do Estado, nem da religião que não seja temporal". ${ }^{15}$

A noção de que existe um poder temporal assim como espiritual é uma armadilha de clérigos ambiciosos com o único fim de favorecer seus próprios interesses. "Governo temporal e espiritual não são mais do que duas palavras trazidas ao mundo, para fazer as pessoas verem duplamente e confundir a legitimidade do seu soberano". ${ }^{16}$

Certamente podíamos ter citado elementos concordantes na Metafísica ou na Física, assim como a pretensão de Hobbes de colocar toda a sua produção em termos lógico-científicos, etc. Porém, não estava nas nossas pretensões construir um índex comparativo de referências paralelas entre dois autores, mas testemunhar de maneira simples a presença viva no pensamento de Hobbes de um autor que ele nunca citou.

\section{Referências bibliográficas}

COSTA, Margarita. La deliberación en Hobbes. Cuadernos de Ética Universidad de Buenos Aires.

Buenos Aires, 1989.

COURTENAY, William J., The academical and Intellectual Worlds of Ockham. In: SPADE, P. V. The

Cambridge Companion to Ockham. Cambridge: Cambridge University Press, 1999, p. 17-30. HOBBES, Thomas, Leviathan. Cambridge: Cambridge University Press, 1991.

- Little Treatise. London : Frank Cass, 1969.

. De Corpore. Illinois: La Salle, 1989.

OAKESHOTT, Michael. Hobbes on civil association. Oxford: The Chaucer Press, 1975.

PETERS, R. S. Hobbes. Baltimor : Penguin, 1986.

RABOSSI, Eduardo. Hobbes y la filosofia del lenguaje. Manuscrito, v. 4, n. 1, 1980, p. 21-28.

TÖNNIES, Ferdinand. Hobbes Vida y Obra. Madrid: Alianza Editorial, 1988.

TUCK, Richard. In: Leviathan. London: Hobbes, Cambridge University Press, 1991. Introduction, p. viiXiv.

WATKINS, John. Hobbe's system of ideas. Vermont: Gower Publishing Company, 1989.

ZARKA, Yves Charles. First philosophy and the foundations of knowledge. In: HOBBES, Sorell. New York: Cambridge University Press, 1996. 